【 - r】

\title{
繰り返しせん断応力を受ける飽和粘土の間隙水圧について PORE WATER PRESSURE OF SATURATED CLAY UNDER CYCLIC SHEAR STRESS
}

大 原 資 生* ・山 本 哲 朗** ・滝 本 邦 彦*** By Sukeo OHARA, Tetsuro YAMAMOTO and Kunihiko TAKIMOTO

\section{1. まえがき}

先に “飽和粘土の動的強度について”と題する論文” を発表し，正現圧密飽和粘土の動的単純せん断試験の結 果を述べ，飽和粘土の動的強度は間隚水圧の発生量によ って決まるということを述べた。

著者は，その後もこの点を確かめるために過圧密飽和 粘土について動的単純せん断試験を行い, その結果を間 幥水圧の発生状況に注目して整理した.

実験は応力制御方式により，非排水せん断試験を行っ た。また，供試体には完全な粘土ということから前に用 いたと同じカオリン粘土を用いた.

以上の実験結果およびその考察について順次述べる.

\section{2. 実験装置および方法}

本実験に用いた 実験装置は前回に用いたものと同じ で, 動的単純せん断試験機などについては前論文 ${ }^{1)}$ で詳 しく説明したので, ここでは改めて述べない.

今回も, 実験は動的試験と静的試験とが行われたが, いずれも非排水状態で過圧密比 (以後, OCR という) が 1 から 4 までの供試体について実験された.

静的試験では，ひずみ速度 $5 \% / \mathrm{min}$ でせん断を行っ た.

また, 動的試験では前回と同様に周期 2 秒の矩形波に 近い波形の繰り返しせん断力を加えて実験を行った.

静的試験, 動的試験いずれもせん断応力, せん断ひず みおよび間幥水圧の変化はすべてペンオシログラフに記 録した.

\footnotetext{
* 正会員 工博 山口大学教授 工学部土木工学科

** 正会員 工修 山口大学助手 工学部土木工学科

*** 正会員 工修 鹿島建設（株）
}

\section{3. 試料および供試体の作製}

本実験に用いた試料は粉末状のカオリン粘土である. 粘土含有率は $98 \%$ できわめて均質な粘土である.この 粘土に含水比が $90 \%$ となるように脱気水を加え，よく 練り合せた後,水分の蒸発を防ぎながら 1 昼夜放置する. その後さらに気泡が完全になくなるまで練り返しを行 う.このようにして作った飽和試料をせん断箱の中へ 3 層に分けて詰め, 1 層ごとに突き棒で突き固める.

そのようにして詰められた供試体を上，下面から排水 可能な状態で所定の圧密圧によって 24 時間圧密する.

圧密後の供試体の寸法は直径 $7.5 \mathrm{~cm}$, 高さ約 $2.0 \mathrm{~cm}$ の円板状である.

過圧密供試体とするには，圧密圧を所要の鉛直圧まで 除荷する. この際に生じる負の間幥水圧は除荷後, 約 1 時間放置することによって消滅させた後にせん断力を加 えた．実験に供した供試体の間嚐比などは表一 1 に示す とおりである。

\section{4. 静的試験}

前回同様に，静的試験の応力ーひずみ曲線はいずれの

表一1 供試体の状態

\begin{tabular}{|c|c|c|c|c|}
\hline \multirow{2}{*}{$\begin{array}{c}\text { Normal } \\
\text { stress } \\
\\
\sigma_{v} \\
\left(\mathrm{~kg} / \mathrm{cm}^{2}\right)\end{array}$} & \multirow{2}{*}{$\begin{array}{c}\text { Pre consoli- } \\
\text { dation } \\
\text { stress } \\
\sigma_{p} \\
\left(\mathrm{~kg} / \mathrm{cm}^{2}\right)\end{array}$} & \multirow{2}{*}{$\begin{array}{c}\text { Over consoli- } \\
\text { dation } \\
\text { ratio } \\
\text { OCR }\end{array}$} & \multicolumn{2}{|c|}{ Void ratio $e$} \\
\hline & & & $\begin{array}{l}\text { after } \\
\text { Nomal con- } \\
\text { solidation }\end{array}$ & $\begin{array}{l}\text { after } \\
\text { Over con- } \\
\text { solidation }\end{array}$ \\
\hline \multirow{4}{*}{0.25} & 0.25 & 1 & 1.45 & 1.45 \\
\hline & 0.5 & 2 & 1.27 & 1.28 \\
\hline & 0.75 & 3 & 1.21 & 1.22 \\
\hline & 1.0 & 4 & 1.18 & 1.19 \\
\hline \multirow{4}{*}{0.5} & 0.5 & 1 & 1.32 & 1.32 \\
\hline & 1.0 & 2 & 1.23 & 1.23 \\
\hline & 1.5 & 3 & 1.15 & 1.16 \\
\hline & 2.0 & 4 & 1.11 & 1.13 \\
\hline
\end{tabular}



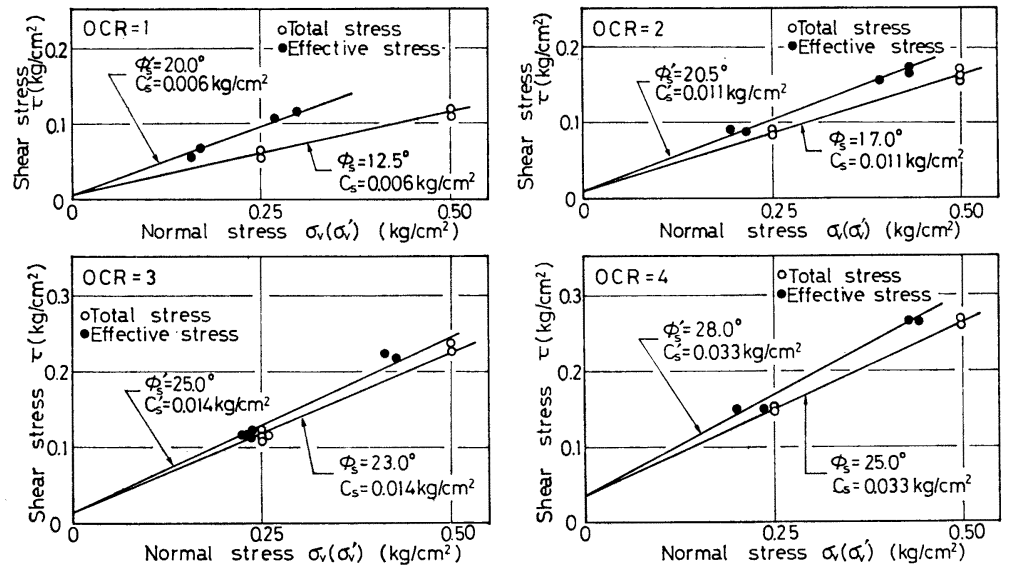

図一1 静的試験結果

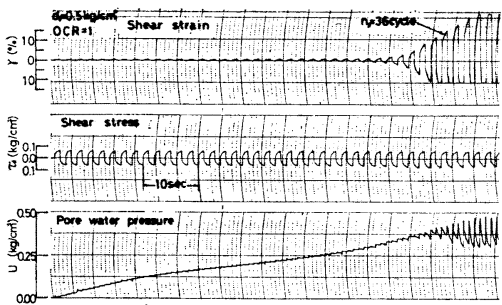

(a)

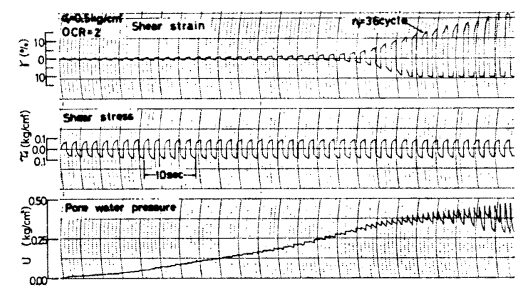

(b)

図一2 動的試験の記録例 が大きいことである.
の OCR 供試体についてもひずみ 量が $15 \%$ のときには, 応力值は 最大值を示しているので，この值 をもってせん断強度とした。

図一1 はその結果から得られた クーロンの破壊線で, 全応力表示 と有効応力表示で示してある. OCR の大きい供試体ほど傾斜角 (内部摩擦角) が大きくなってお り, 全応力表示と有効応力表示と が接近し, 間隚水圧の生じ方が少 ないことがわかる。

\section{5. 動 的 試 験}

図一2 は動的試験の記録例を示したものである.（a） が正規圧密供試体，(b) が過圧密供試体 $(\mathrm{OCR}=2.0)$ に よるもので, 両者の違いはせん断ひずみの増加が (a) の 方が急であることと, 間隚水圧の増加の速度も (a)の方

静的せん断試験結果との対忍を考えて，このような記 録からせん断ひずみが $15 \%$ に達したときまでのせん断 応力の繰り返し回数を, 供試体の破壊に要する繰り返し 回数 $n_{f}$ とし, その際に負荷された繰り返しせん断応力 $\tau_{d}$ の初期有効鉛直圧 $\sigma_{v}$ に対する比 $\tau_{d} / \sigma_{v}$ との関係を 示したのが図一3である.

$n_{f}$ の増大に従って $\tau_{d} / \sigma_{v}$ が低下しており, 実験值に $\sigma_{v}$ の違いによるばらつきが目立つ場合もあるが, $\tau_{d} / \sigma_{v}$ と $n_{f}$ との関係は, OCR ごとにほぼ 1 本の直線で表わ し得るとみることができる.

図一3 に示される結果は飽和砂の液状化の場合と非常

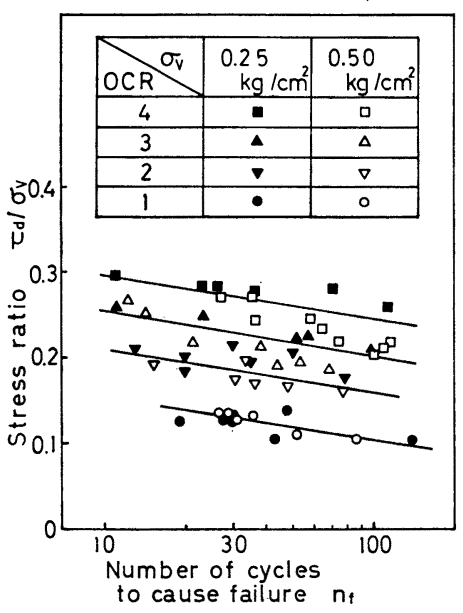

図一3 応力比 $\tau_{d} / \sigma_{v}$ と $n_{f}$ との関係
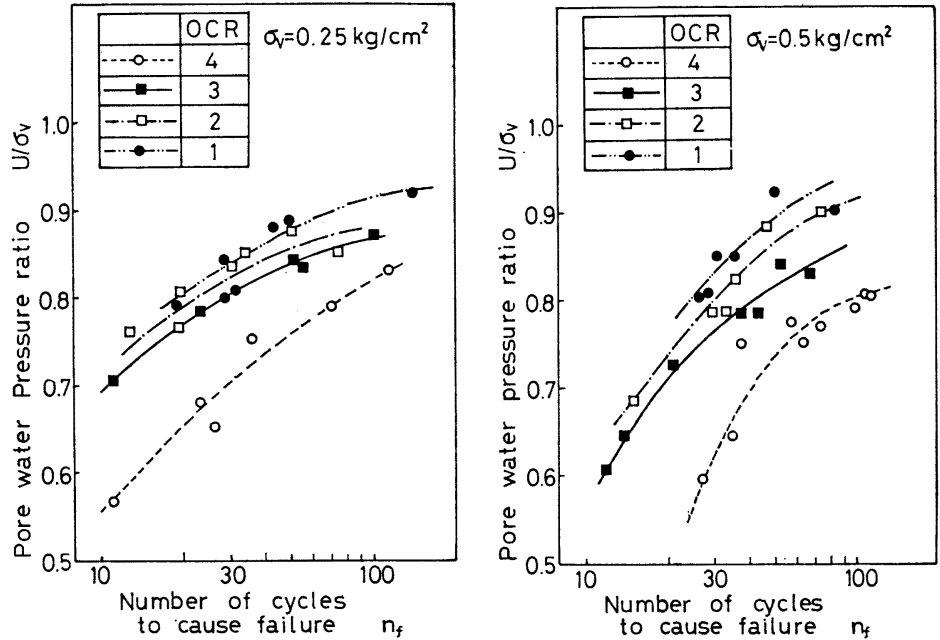

図-4 間隙水圧比 $\boldsymbol{u} / \boldsymbol{\sigma}_{v}$ と $\boldsymbol{n}_{f}$ との関係 


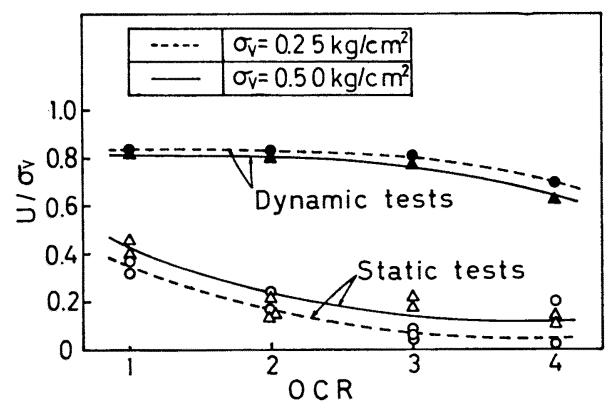

図一5 $n_{f}=30$ における $u / \sigma_{v}$ と OCR との関係

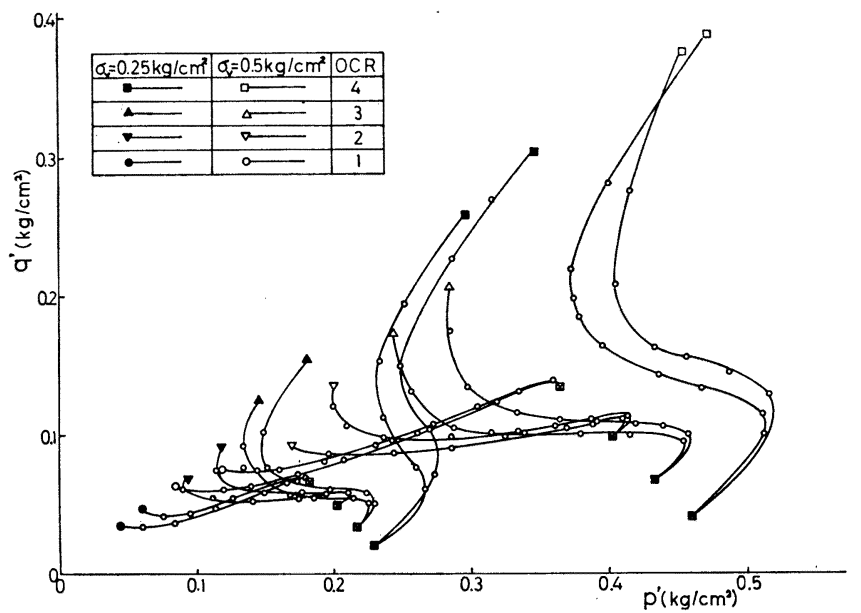

図一6 動的試験時の応力径路

によく類似している. すなわち砂質土の液状化の実験結 果では応力比 $\tau_{d} / \sigma_{v}$ と $n_{f}$ との関係は, それぞれの OCR ごとに 1 本の線で示されることがわかっているが, この 飽和粘土についても同様な結果が得られていることは興 味深い.

図一4 は破壊時の間隚水圧比 $u / \sigma_{v}$ と破壊に至るまで の絽り返し回数 $n_{f}$ との関倸を示すもので，これより $n_{f}=30$ の $u / \sigma_{v}$ をとって OCR との関係を示したもの が図一5である.

この図中に静的試験における破壊時の $u / \sigma_{v}$ と OCR と の関係も記載した. OCR の大きい場合が $u / \sigma_{v}$ の值が小 さくなっている点は動的試験の結果も静的試験のそれも 変わらないが, 両者の間には減少の傾向に差が認められ る.

また，兩者の $u / \sigma_{v}$ の值に大きい差があることが注目 すべきことであろう．すなわち動的試験では，供試体の 破壊は $u / \sigma_{v}$ が 0.8 程度で生じている. この値は静的試 験の場合のそれより非常に大きい值である.

結局は動的試験時の間隚水圧の発生量は大きいという ことである.

このように，供試体に繰り返しせん断力が負荷された

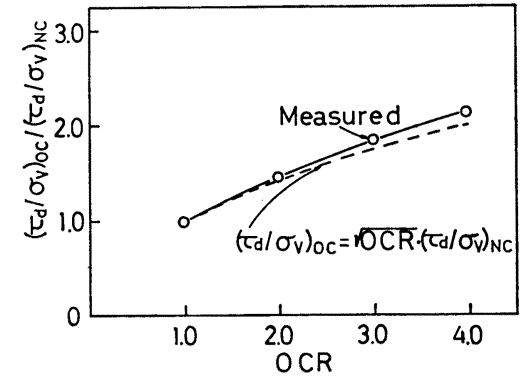

図一7 応力比と OCR との関係

状態では間嚐水圧の発生量が大きくなること は砂質土の液状化と同様である.

間隚水圧の発生挙動については, 応力径路 によって考察するのが便利である.しかし， この実験に用いた単純せん断試験機では側圧 を制御できないので，静止土圧係数 $K_{0}$ が不 明で正確な有効主応力が把握できない，そこ で $K_{0}$ 值として, 過圧密粘土の場合について も Brooker らが提案し ている值”を用いること にした.

$$
\text { すなわち表一2のよう }
$$

に $K_{0}$ 值を定めた*.

そして,この $K_{0}$ 值を

\begin{tabular}{c|c} 
表一 & $\boldsymbol{K}_{0}$ 值 \\
\hline OCR & $K_{0}$ \\
\hline 1 & 0.46 \\
2 & 0.61 \\
3 & 0.73 \\
4 & 0.84 \\
\hline
\end{tabular}

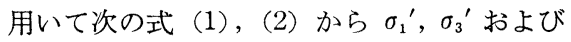
$p^{\prime}, q^{\prime}$ を求め, 動的試験時の応力径路を書いたのが 図一 6 である.なお，式 (1) は前論文 ${ }^{1)}$ で導いたものである.

$$
\begin{aligned}
& \left.\begin{array}{l}
\sigma_{1}{ }^{\prime}=\left\{\left(1-K_{0}\right) \sigma_{v}{ }^{2}+\tau_{d}{ }^{2}\right\} /\left(1-K_{0}\right) \sigma_{v}{ }^{\prime} \\
\sigma_{3}{ }^{\prime}=K_{0} \sigma_{v}{ }^{\prime}
\end{array}\right\} \\
& p^{\prime}=\frac{\sigma_{1}{ }^{\prime}+\sigma_{3}{ }^{\prime}}{2}=\left\{\sigma_{v}{ }^{2}\left(1-K_{0}{ }^{2}\right)+\tau_{d}{ }^{2}\right\} / \\
& \left\{2\left(1-K_{0}\right) \sigma_{v}{ }^{\prime}\right\} \\
& q^{\prime}=\frac{\sigma_{1}{ }^{\prime}-\sigma_{3}{ }^{\prime}}{2}=\left\{\sigma_{v}{ }^{2}\left(1-K_{0}\right)^{2}+\tau_{d^{2}}{ }^{2}\right\} \\
& \left\{2\left(1-K_{0}\right) \sigma_{v}{ }^{\prime}\right\}
\end{aligned}
$$

ここで, $\sigma_{1}{ }^{\prime}, \sigma_{3}{ }^{\prime}$ : 有効主応力, $\tau_{d}$ : 繰り返しせん断応 力, $\sigma_{v}{ }^{\prime}:$ 有効鉛直圧である.

図一6より OCR によって応力径路が大きく異なるこ とがわかる. 出発点（初期状態）と破壊点との水平距離 が大きいほど間隙水圧の発生量が大きいことを示すの で, OCR $=1.0$ の場合がその発生量が最も大きく, OCR が大きくなるに従って順次小さくなる.

* この実験に用いた飽和粘土の正規圧密の場合の内部摩擦角 は 3 軸試験結果の有効応力表示で $29^{\circ}$ となっている. Brooker らは $\mathrm{OCR}=1.0$ の場合は $K_{0}=0.95-\sin \phi^{\prime}$ の式を提 案しているが, $\phi^{\prime}=29^{\circ}$ とすると $K_{0}=0.46$ となる. この值 は Brooker らの実験値とよく一致していることから，他の OCR の值での $K_{0}$ 值も Brooker らの実験値を用いた. 
以上の結果から動的試験時に生じる間隚水圧は静的試 験時のそれの数倍になることがわかる.

また, 図一3 の結果から $n_{f}=30$ のときの $\tau_{d} / \sigma_{v}$ の值 を求め, $\mathrm{OCR}=1.0$ のときの值を $\left(\tau_{d} / \sigma_{v}\right)_{N C}$, 過圧密状 態 $(\mathrm{OCR}>1.0)$ のときの值を $\left(\tau_{d} / \sigma_{v}\right)$ OC とする. 縦軸 に両者の比 $\left(\tau_{d} / \sigma_{v}\right)_{O C} /\left(\tau_{d} / \sigma_{v}\right)_{N C}$ をとり, 横軸に OCR をとると図一7が得られる.

石原らは, 砂質土の液状化に対する過圧密比の影響を みるために, この方法を提案し, 次の関係式を導いてい る ${ }^{3)}$.

$$
\left(\tau_{d} / \sigma_{v}\right)_{O C}=\sqrt{\mathrm{OCR}}\left(\tau_{d} / \sigma_{v}\right)_{N C}
$$

図一7の中の点線が式 (3) の值である.これより,こ の実験に用いた粘土についても，ほぼ式 (3) の関係が成 り立っていることがわかる。

\section{6. 結 語}

飽和粘土の動的強度を調べることを目的にして，正規 圧密粘土および過圧密粘土について動的単紝ん断試験 を行った. その際の供試体中の間腺水圧の発生挙動に注 目して実験結果を考察し, 次の結論を得た.

（1）飽和粘土の動的強度は間隚水圧の発生量に大き

\section{く影響される。}

（2）繰り返しせん断态力の作用によって生じる破壊 時の間紡水圧は静的せん断匛力負荷時のそれよりかなり 大きい.

（3）後者に対する前者の比率は過圧密比によって異 なるが, 正規圧密粘土で約 2 , 過圧密比 4 で約 $4 \sim 6$ と なっている。

（4）飽和粘土の動的強度に対する過圧密比の影響は 式 (3) で示され砂質土の液状化に対するそれと同一であ る.

最後に, 本実験を行うにあたって本学大学院生 生田 裕彦君の助力をいただいた，厚く謝意を表する.

\section{参考 文 献}

1）大原資生・松田 博 : 飽和粘土の動的強度について, 土 木学会論文報告集, 第 274 号, pp. 69 78, 1978 年 6 月.

2) Brooker, E.W. and H.O. Ireland : Earth Pressures at Rest Related to Stress History, Canadian Geotechnical Journal, Vol. 2, pp. 1 15, Feb. 1965.

3) Ishihara, K. and H. Takatsu : Effects of Overconsolidation and $K_{0}$ Conditions on the Liquetaction Characteristics of Sands, Soils and Foundations, Vol. 19, No. 4, pp. 31 42, Dec., 1979. 